\title{
Preparation of Barium Strontium Titanate Powder from Citrate Precursor
}

\author{
Chen-Feng Kao* and Wein-Duo Yang \\ Department of Chemical Engineering, National Cheng Kung University, Tainan, 70101, Taiwan
}

$\mathrm{TiCl}_{4}$ or titanium isopropoxide reacted with citric acid to form a titanyl citrate precipitate. Barium strontium citrate solutions were then added to the titanyl citrate reaction to form gels. These gels were dried and calcined to $(\mathrm{Ba}, \mathrm{Sr})$ $\mathrm{TiO}_{3}$ powders. The gels and powders were characterized by DSC/TGA, IR, SEM and XRD analyses. These results showed that, at $500{ }^{\circ} \mathrm{C}$, the gels decomposed to $\mathrm{Ba}, \mathrm{Sr}$ carbonate and $\mathrm{TiO}_{2}$, followed by the formation of $(\mathrm{Ba}, \mathrm{Sr})-$ $\mathrm{TiO}_{3}$. The onset of perovskite formation occurred at $600{ }^{\circ} \mathrm{C}$, and was nearly complete at $1000{ }^{\circ} \mathrm{C}$. Traces of $\mathrm{SrCO}_{3}$ were still present.

The cation ratios of the titanate powder prepared in the pH range 5-6 were closest to the original stoichiometry. Only $0.1 \mathrm{~mol} \%$ of the free cations remained in solution. The titanyl citrates were precipitated in either ethanol or acetone. The acetone-derived precipitates were always viscous, but those with a sufficient quantity of alcohol were powdery.

The specific surface areas of the ceramic powders obtained by air-, vacuum- and freezedrying methods were $8.3 \times 10^{3}, 10.2 \times 10^{3}$ and $12.5 \times 10^{3} \mathrm{~m}^{2} \mathrm{~kg}^{-1}$, respectively. The powder obtained by freeze-drying had the lowest degree of agglomeration. The precipitated powders of titanyl citrate which were freeze-dried and calcined at $1100{ }^{\circ} \mathrm{C}$ were compacted and sintered at $1300{ }^{\circ} \mathrm{C}$ to obtain dense ceramic bodies with $95 \%$ of the theoretical density. Copyright (C) 1999 John Wiley \& Sons, Ltd.

Keywords: barium strontium titanate; citrate method; titanyl citrate precursor

\footnotetext{
* Correspondence to: Chen-Feng Kao, Department of Chemical Engineering, National Cheng Kung University, Tainan, 70101, Taiwan.

Contract/grant sponsor: National Science Council; Contract/grant number: NSC 85-2214-E006-003.
}

\section{INTRODUCTION}

$\mathrm{BaTiO}_{3}$ is ferroelectric and piezoelectric and has extensive applications as an electronic material. It can be used as a capacitor, thermistor, transducer, accelerometer or degausser of colour television. $\mathrm{BaTiO}_{3}$ doped with strontium retains its original characteristics but has a lower Curie temperature for positive temperature coefficient devices under various conditions.

Besides solid-state reactions, chemical reactions have also been used to prepare $\mathrm{BaTiO}_{3}$ powder. Among them the hydrolysis of metal alkoxide ${ }^{1}$, oxalate precipitation in ethanol ${ }^{2}$, and alcoholic dehydration of citrate solution ${ }^{3}$ are among the more attractive methods. In 1956 Clabaugh et al. $^{4}$ described the preparation of barium titanyl oxalate tetrahydrate for conversion to high-purity barium titanate. Kudaka et al. ${ }^{5}$ also prepared stoichiometric barium titanyl oxalate tetrahydrate. Many elements are quite soluble in citric acid, ${ }^{6}$ so a citrate precursor appeared to be useful for preparing titanate powders. Indeed, barium titanyl citrate precursors have become a very important route to prepare $\mathrm{BaTiO}_{3}$.

In this study, barium strontium titanyl citrate gels were used to produce $(\mathrm{Ba}, \mathrm{Sr}) \mathrm{TiO}_{3}$ powders. Besides investigating the effect of the water content and $\mathrm{pH}$ of the starting solutions, and the $\mathrm{Ba} / \mathrm{Sr}$ stoichiometry needed to obtain optimum reaction conditions, we also studied the chemistry and thermogravimetric behaviour of the precursors during calcining, in order to understand the crystal and microstructure changes.

The $\mathrm{BaTiO}_{3}$ phase transformations ${ }^{7}$ are shown in Scheme 1.

$$
120^{\circ} \mathrm{C} \quad 0^{\circ} \mathrm{C} \quad-90^{\circ} \mathrm{C}
$$

cubic $\rightarrow$ tetragonal $\rightarrow$ monoclinic $\rightarrow$ rhombohedral

$$
\text { Scheme } 1 \mathrm{BaTiO}_{3} \text { phase transformations. }
$$

The addition of $\mathrm{Ca}, \mathrm{Sr}$ and $\mathrm{Pb}$ dopant permits one to change the Curie temperature of $\mathrm{BaTiO}_{3} ;{ }^{8}$ the change can be calculated, depending on how much dopant is added. Andrich reported that each 
mole $\% \mathrm{SrTiO}_{3}$ added lowered the Curie temperature of $\mathrm{BaTiO}_{3}$ from $125^{\circ} \mathrm{C}$ by $-3 \%$ and each mole $\% \mathrm{PbTiO}_{3}$ added raised the Curie temperature by $+5 \%$. Hence $\left(\mathrm{Ba}_{1-x} \mathrm{Sr}_{x}\right) \mathrm{TiO}_{3}$ and $\left(\mathrm{Ba}_{1-x} \mathrm{~Pb}_{x}\right)$ $\mathrm{TiO}_{3}$ can be tailored so that a given positive temperature coefficient device can operate either above or below $125^{\circ} \mathrm{C}$ (Eqns [1] and [2]).

$$
\begin{array}{r}
\mathrm{BaTiO}_{3}+\mathrm{SrTiO}_{3} \rightarrow\left(\mathrm{Ba}_{1-x} \mathrm{Sr}_{x}\right) \mathrm{TiO}_{3} \\
T_{\mathrm{c}}<125^{\circ} \mathrm{C} \\
\mathrm{BaTiO}_{3}+\mathrm{PbTiO}_{3} \rightarrow\left(\mathrm{Ba}_{1-x} \mathrm{~Pb}_{x}\right) \mathrm{TiO}_{3} \\
T_{\mathrm{c}}>125^{\circ} \mathrm{C}
\end{array}
$$

\section{Synthesis of $(\mathrm{Ba}, \mathrm{Sr}) \mathrm{TiO}_{3}$ powder}

\section{Solid-state reaction}

$\mathrm{BaCO}_{3}, \mathrm{SrCO}_{3}$ and $\mathrm{TiO}_{2}$ can be mixed and calcined at $1100-1200{ }^{\circ} \mathrm{C}$ to give $(\mathrm{Ba}, \mathrm{Sr}) \mathrm{TiO}_{3}$ powders (Eqn [3]).

$$
\begin{array}{r}
\mathrm{SrCO}_{3}+\mathrm{BaCO}_{3}+\mathrm{TiO}_{2} \rightarrow(\mathrm{Ba}, \mathrm{Sr}) \mathrm{TiO}_{3}+ \\
\mathrm{CO}_{2} \uparrow
\end{array}
$$

The advantages are simplicity and low cost, but the disadvantages are that the high calcining temperature results in very large grain sizes and therefore cannot be used to obtain materials with a high dielectric constant; ${ }^{10}$ if we want fine powder, grinding is required, leading to pollution problems; moreover, the mixing of large amounts of starting materials is not easy and can produce mixtures of $\mathrm{Ba}_{2} \mathrm{TiO}_{4}, \mathrm{Ba}_{6} \mathrm{Ti}_{17} \mathrm{O}_{10}$ and $\mathrm{BaTi}_{4} \mathrm{O}_{9}$ phases as sideproducts.

\section{Chemical reaction methods}

To obtain $\mathrm{BaTiO}_{3}$ particles smaller than $0.7 \mu \mathrm{m}$, with dielectric constants of 5000-6000, chemical reaction methods have been developed to control both phase formation and grain growth, leading to uniform fine particles.

The chemical reaction methods currently used to prepare $\mathrm{BaTiO}_{3}$ can be classified as follows.

\section{Spray drying and roasting techniques}

$\mathrm{Ba}^{2+}, \mathrm{Sr}^{2+}$ and $\mathrm{Ti}^{4+}$ solutions are mixed at high temperature and then converted to $(\mathrm{Ba}, \mathrm{Sr}) \mathrm{TiO}_{3}$ through thermal decomposition. ${ }^{10}$ The advantage of this process is the low deviation from stoichiometry. The disadvantages are: (a) agglomeration which requires grinding and (b) hundreds of parts per million of $\mathrm{Cl}^{-}$that remain to occupy the positions of the oxygen atoms in $\mathrm{BaTiO}_{3}$.
Metal alkoxide hydrolysis (sol-gel method)

As there are many alkoxides which can be used in sol-gel methods, controlling the powder uniformity, better chemical stoichiometry and high purity can be attained than when using conventional ceramic powder processing. ${ }^{11}$ The method involves dissolving alkoxides of titanium and barium in organic solvent and adding water at appropriate temperatures to hydrolyse these alkoxides to precipitate the mixed oxides. The reaction can be described by Eqn [4].

$$
\begin{aligned}
& \mathrm{Ba}\left(\mathrm{OC}_{3} \mathrm{H}_{7}\right)_{2}+\mathrm{Ti}\left(\mathrm{OC}_{5} \mathrm{H}_{11}\right)_{4}+3 \mathrm{H}_{2} \mathrm{O} \rightarrow \\
& \mathrm{BaTiO}_{3} \downarrow+2 \mathrm{C}_{3} \mathrm{H}_{7} \mathrm{OH}+4 \mathrm{C}_{5} \mathrm{H}_{11} \mathrm{OH}
\end{aligned}
$$

The shortcomings of this approach are chemical instability of the metal alkoxides, the complexity of the process and the high cost. Therefore this method is unsuitable for mass production.

\section{Hydrothermal synthesis}

This method can be used at very low temperatures to prepare multicomponent perovskite powders. ${ }^{12}$ For example, at $120-130{ }^{\circ} \mathrm{C}$ and 5-50 bar, one can synthesize $\mathrm{BaTiO}_{3}$ and $\mathrm{SrTiO}_{3}$ powders from titanium hydroxide and barium and strontium solutions. ${ }^{12} \mathrm{BaTiO}_{3}$ can be easily obtained from $\mathrm{TiOCl}_{2}$ and $\mathrm{BaCl}_{2}$ in $\mathrm{NaOH}$ solution to prepare uniform-size, spherical grains of ultrafine powder. In hydrothermal synthesis, however, incomplete reactions and inappropriate $\mathrm{Ba} / \mathrm{Ti}$ ratios make it necessary to supplement the mixture with an excess barium or titanium ions to maintain chemical stoichiometry, as precipitation leads to loss of metal ions.

\section{Synthesis from a complex precursor}

Clabaugh ${ }^{4}$ prepared barium titanyl oxalate tetrahydrate for conversion to high-purity barium titanate, but the disadvantage is that barium titanate does not exist in neutral solution. To obtain appropriate cation ratios, one must control the precipitation process carefully. ${ }^{10}$ Kudaka et al. ${ }^{5}$ indicated that the $\mathrm{Ba}^{2+} / \mathrm{Ti}^{4+} / \mathrm{C}_{2} \mathrm{O}_{4}{ }^{2-}$ ratio should be $1.05: 1: 2.2$ to obtain a product with $\mathrm{Ba} / \mathrm{Ti}=1.0$. Because $\mathrm{BaCO}_{3}$ is very stable and not easily decomposed, $\mathrm{BaTiO}\left(\mathrm{C}_{2} \mathrm{O}_{4}\right)_{2} \cdot 4 \mathrm{H}_{2} \mathrm{O}$ is calcined in air, not to $\mathrm{BaTiO}_{3}$, but to the intermediate $\mathrm{Ba}_{2} \mathrm{Ti}_{2} \mathrm{O}_{5} \cdot \mathrm{CO}_{3}$, and only over $700^{\circ} \mathrm{C}$ does the intermediate decompose to form $\mathrm{BaTiO}_{3}$ powder. ${ }^{13}$ Consequently, atomically mixed $\mathrm{BaTiO}_{3}$ from this oxalate complex precipitate precursor is not obtained easily.

Appl. Organometal. Chem. 13, 383-397 (1999) 


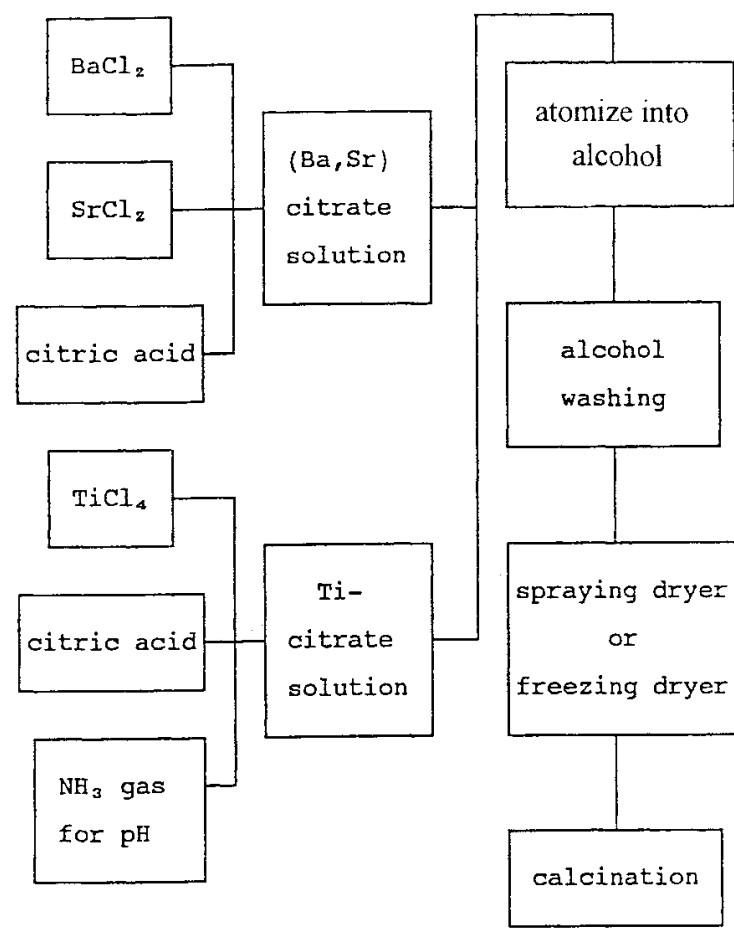

Figure 1 Flowchart for the preparation of $(\mathrm{Ba}, \mathrm{Sr}) \mathrm{TiO}_{3}$ powders from citrate.

\section{Citrate process}

In this method, tetrabutyl titanate, citric acid and ethylene glycol are mixed to give a solution and then barium carbonate, dissolved in formic acid and water, is added; ${ }^{10}$ then the $\mathrm{pH}$ is adjusted to induce coprecipitation at $\mathrm{Ba} / \mathrm{Ti}=1: 1$ of $\mathrm{BaTi}\left(\mathrm{C}_{6} \mathrm{H}_{6} \mathrm{O}_{7}\right)_{3} \cdot 4 \mathrm{H}_{2} \mathrm{O} .{ }^{14}$ Under optimum conditions, one should consider the concentrations of citric acid and ethylene glycol, and the mole ratio of

Table 1. Conditions for precursor coprecipitation with $\mathrm{C}_{2} \mathrm{H}_{5} \mathrm{OH} /$ citrate (13:1) at various $\mathrm{pH}$ values

\begin{tabular}{lcc}
\hline $\mathrm{pH}$ & $\mathrm{C}_{2} \mathrm{H}_{5} \mathrm{OH} /$ citrate & $\mathrm{Ba} / \mathrm{Sr} / \mathrm{Ti}$ (mol ratio) \\
\hline $2-3$ & $13: 1$ & $1: 1: 2$ \\
$2-3$ & $13: 1$ & $1: 0: 1$ \\
$3-4$ & $13: 1$ & $1: 1: 2$ \\
$4-5$ & $13: 1$ & $1: 1: 2$ \\
$5-6$ & $13: 1$ & $1: 1: 2$ \\
$5-6$ & $13: 1$ & $0: 1: 1$ \\
$7-8$ & $13: 1$ & $1: 1: 2$ \\
\hline
\end{tabular}

Copyright (C) 1999 John Wiley \& Sons, Ltd.
Table 2. Conditions for precursor coprecipitation at various solvent ratios

\begin{tabular}{lcc}
\hline Solvent & $\mathrm{Ba} / \mathrm{Sr} / \mathrm{Ti}(\mathrm{mol})$ & $\begin{array}{c}\text { Solvent/precursor } \\
\text { (volume ratio) }\end{array}$ \\
\hline Ethanol & $1: 1: 2$ & $8: 1$ \\
& $1: 1: 2$ & $10: 1$ \\
& $1: 1: 2$ & $13: 1$ \\
& $1: 1: 2$ & $15: 1$ \\
Acetone & $1: 1: 2$ & $20: 1$ \\
& $1: 1: 2$ & $8: 1$ \\
& $1: 1: 2$ & $10: 1$ \\
& $1: 1: 2$ & $13: 1$ \\
& $1: 1: 2$ & $15: 1$ \\
\hline
\end{tabular}

$(\mathrm{Ba}+\mathrm{Ti}) /($ citric acid + ethylene glycol). The precursor after heat treatment in air produces $\mathrm{BaTiO}_{3}$, obtained via a solid-state reaction between intermediate species. ${ }^{12}$

It is noteworthy that the $\mathrm{Ba} / \mathrm{Ti}$ ratio in solution should be $1: 1$ at $\mathrm{pH}<2.6$, and $2: 1$ at $\mathrm{pH}>3.2$.

This liquid mixing process has been used to synthesize over one hundred different oxides, ${ }^{14}$ including titanates, zirconates and niobates. The advantages of this process are: good control of chemical stoichiometry, low processing temperatures $\left(<800^{\circ} \mathrm{C}\right)$; and easy dopant addition. The disadvantages are the very large mass losses during calcination and agglomeration.

\section{EXPERIMENTAL}

\section{Chemicals}

Barium chloride $\left(\mathrm{BaCl}_{2} \cdot 2 \mathrm{H}_{2} \mathrm{O},>99 \%\right.$ purity; Ferak), strontium chloride $\left(\mathrm{SrCl}_{2} \cdot 6 \mathrm{H}_{2} \mathrm{O}, \mathrm{EP}\right.$; Hayashi), anhydrous titanium (IV) chloride ( $\mathrm{TiCl}_{4}, \mathrm{EP}$, $>99.5 \%$ purity; Shimakyu) and titanium (IV) isopropoxide $\left\{\left[\left(\mathrm{CH}_{3}\right)_{2} \mathrm{CHO}\right]_{4} \mathrm{Ti}, \quad>98 \%\right.$ purity; Janssen $\}$ were used as the starting reagents for $\mathrm{Ba}(\mathrm{II}), \mathrm{Sr}(\mathrm{II})$ and $\mathrm{Ti}(\mathrm{IV})$, respectively. Citric acid monohydrate $\left[\mathrm{HOC}(\mathrm{COOH})\left(\mathrm{CH}_{2} \mathrm{COOH}\right)_{2} \cdot \mathrm{H}_{2} \mathrm{O}\right.$, EP; Merck] was used as the reagent. Water used was of spectroscopic grade. Ethyl alcohol $\left(\mathrm{C}_{2} \mathrm{H}_{5} \mathrm{OH}\right.$, EP, $99.5 \%$; Shimakyu) or acetone $\left(\mathrm{CH}_{3} \mathrm{COCH}_{3}, \mathrm{EP}\right.$; Santoku) was used as the solvent. Polyvinyl alcohol 2000 (PVA; $5 \mathrm{wt} \%,>98.5 \%$ purity; Showa) was mixed with the calcined powder.

Appl. Organometal. Chem. 13, 383-397 (1999) 


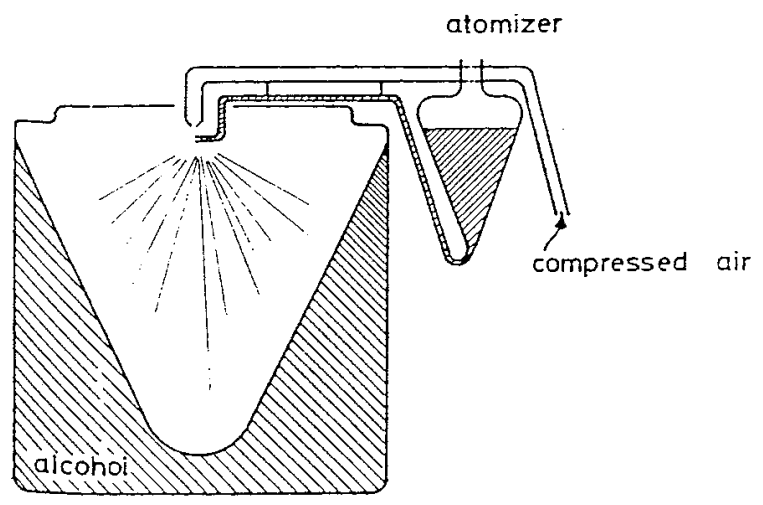

Figure 2 Set-up for coprecipitation.

\section{Procedures}

\section{Preparation of citrate precursor}

(A) Preparation of barium strontium citrate $\mathrm{BaCl}_{2} \cdot 2 \mathrm{H}_{2} \mathrm{O}(6.1070 \mathrm{~g} ; \quad 0.025 \mathrm{~mol}), \quad \mathrm{SrCl}_{2}$. $6 \mathrm{H}_{2} \mathrm{O}(6.665 \mathrm{~g} ; \quad 0.025 \mathrm{~mol})$ and $\mathrm{HOC}(\mathrm{COOH})$ $\left(\mathrm{CH}_{2} \mathrm{COOH}\right)_{2} \cdot \mathrm{H}_{2} \mathrm{O}(21.015 \mathrm{~g} ; \quad 0.1 \mathrm{~mol})$, were weighed to make the ratio of $(\mathrm{Ba}+\mathrm{Sr}) /($ citric acid) $1: 2$, then $300 \mathrm{ml}$ of water was added to dissolve the mixture and it was diluted to $500 \mathrm{ml}$ with water to make the citric acid concentration $0.2 \mathrm{M}$.

\section{(B) Preparation of titanium citrate}

$\mathrm{TiCl}_{4}$ was hydrolysed in an ice bath and titanium was precipitated by cupferron. ${ }^{15}$ The precipitate was then calcined at $1000{ }^{\circ} \mathrm{C}$ for $4 \mathrm{~h}$ to form $\mathrm{TiO}_{2}$, to determine the extent of the hydrolysis of the $\mathrm{TiCl}_{4}$. Citric acid $(2 \mathrm{~mol} / \mathrm{mol}$ titanium ion) was mixed with the hydrolysed $\mathrm{TiCl}_{4}$, water was added to adjust the concentration of titanium to $0.2 \mathrm{M}$, and anhydrous $\mathrm{NH}_{3}$ gas (Air Products) was added to adjust the $\mathrm{pH}$ value during the mixing process.

\section{(C)Preparation of citrate precursor}

Barium strontium citrate from (A) was mixed with titanium citrate from (B) with stirring to give a clear citrate precursor. The flowchart for the preparation of citrate precursor is shown in Figure 1. The conditions for precursor coprecipitation at various $\mathrm{pH}$ values and solvent ratios are listed in Tables 1 and 2 , respectively.

\section{Precipitation of citrate precursor}

The solution of citrate precursor was sprayed by compressed air into 8-20 vol. of absolute ethanol or acetone to give a white precipitate (Fig. 2). The precipitate was then filtered, washed with ethanol and filtered again.

\section{Drying and grinding}

The precursor made in step (C) was dried in an air oven, vacuum oven and freeze-dryer, sequentially, and the temperature was maintained at $80^{\circ} \mathrm{C}$ for $24 \mathrm{~h}$. Ethanol was added as appropriate and the product was wet-ground in a cornelian mortar until the ethanol had evaporated. The sample was then dried for $\sim 8 \mathrm{~h}$ to ensure complete removal of ethanol.

\section{Pressing and sintering}

The calcined powder was mixed with $5 \mathrm{wt} \%$ PVA solution and compacted in a steel die with i.d. $0.013 \mathrm{~m}$, at $110 \mathrm{MPa}$. The pellets were heated at a rate of $10{ }^{\circ} \mathrm{C} \mathrm{min}{ }^{-1}$ to $1100,1200,1300$ and $1450{ }^{\circ} \mathrm{C}$, respectively, for $4 \mathrm{~h}$ in air, and furnacecooled.

\section{Solid-state reaction}

The sample was mixed in the mole ratio $\mathrm{SrCO}_{3} /$ $\mathrm{BaCO}_{3} / \mathrm{TiO}_{2}=1: 1: 1$ and then calcined at $1100^{\circ} \mathrm{C}$ in an alumina crucible for $8 \mathrm{~h}$. The calcined sample was pressed into the mould, then the material was removed from the mould and sintered at $1450{ }^{\circ} \mathrm{C}$ for $4 \mathrm{~h}$. Various properties of this sample were compared with those of the sample made by the citrate precursor route.

\section{Instrumental methods}

To understand the influence of the synthesis conditions, such as $\mathrm{pH}$ and solvent, on the precursor and final ceramic powder morphology, we freezedried the precipitate after washing it with ethanol. Infrared spectroscopy (IR), differential scanning calorimetry (DSC), thermogravimetric analysis (TGA), X-ray diffraction (XRD) and Brunauer, Emmett and Teller (BET) surface area studies were

Table 3. Preparation of titanyl citrate precursor at various $\mathrm{pH}$ values

\begin{tabular}{ccc}
\hline $\mathrm{pH}$ & $\mathrm{Ba} / \mathrm{Sr} / \mathrm{Ti}(\mathrm{mol})$ & Solution character \\
\hline $2-3$ & $1: 1: 2$ & Precipitation \\
$2-3$ & $1: 0: 1$ & Clear \\
$3-4$ & $1: 1: 2$ & Precipitation \\
$4-5$ & $1: 1: 2$ & Clear \\
$5-6$ & $1: 1: 2$ & Clear \\
$5-6$ & $0: 1: 1$ & Clear \\
$7-8$ & $1: 1: 2$ & Precipitation \\
\hline
\end{tabular}


Table 4. Preparation of titanyl citrate precursor in various solvents and at various ratios of solvent/ precursor

\begin{tabular}{lccccc}
\hline & & & \multicolumn{2}{c}{ Soln concn (\%) } \\
\cline { 3 - 5 } Solvent & $\begin{array}{c}\text { Solvent/precursor } \\
\text { (volume ratio) }\end{array}$ & Properties & $\mathrm{Ba}$ & $\mathrm{Sr}$ & $\mathrm{Ti}$ \\
\hline Ethanol & $8: 1$ & Wet gel & 3.0 & 3.5 & 3.2 \\
& $10: 1$ & Gel & 1.5 & 2.2 & 1.7 \\
& $13: 1$ & Powder & 0.1 & 0.2 & 0.1 \\
Acetone & $15: 1$ & Powder & 0.1 & 0.1 & -1 \\
& $20: 1$ & Powder & - & 4.0 & 3.8 \\
& $8: 1$ & Wet gel & 4.2 & 2.3 & 2.3 \\
& $10: 1$ & Gel & 2.2 & 0.6 & 0.8 \\
\hline
\end{tabular}

used to analyse the precursor and powder. The chemical composition of the filtrate was analysed by atomic absorption spectroscopy (AA). Scanning electroon microscopy (SEM) and mapping were used to analyse the microstructures and uniformities of the precursor, powder and sintered bodies. The cross-section of the sintered body was polished with fine diamond grits and etched in $1.5 \mathrm{M}$ nitric acid at $343-353 \mathrm{~K}$ for $1 \mathrm{~h}$ and then subjected to d.c. sputter-coating. It was investigated for grain growth at various sintering temperatures by SEM.

\section{RESULTS AND DISCUSSION}

\section{Precursor studies}

Effect of $\mathbf{p H}$

The barium strontium titanyl citrate precursor is a clear solution in a specific $\mathrm{pH}$ range. ${ }^{16}$ Details of the preparation of titanyl citrate precursor at various $\mathrm{pH}$ values are listed in Table 3. It is clear from Table 3 that precipitation occurs in neutral or alkaline solutions. Only barium and titanium cations at $\mathrm{pH} 2-3$ result in a clear solution. Strontium and titanium cations at $\mathrm{pH} 4-6$ result a clear solution.

\section{Effect of solvent}

A series of titanyl citrate precursor solutions were prepared in various solvents and in varying solvent/ precursor ratios as listed in Table 4. When less solvent is used, the precursor forms a wet gel with more cations remaining in solution. When the solvent/precursor ratio is greater than 13, white powders result. The concentration of cation in filtrates, as analysed by AA, is very low, about 0.1 $\%$. When more solvent is used, the amount of the<smiles>O=C([O-])CC(O)CC(=O)O</smiles><smiles>[O-][Mg]</smiles>

Citrate<smiles>[17CH3]CC(CC(=O)[O-])C(=O)[O-]</smiles>

Itaconate

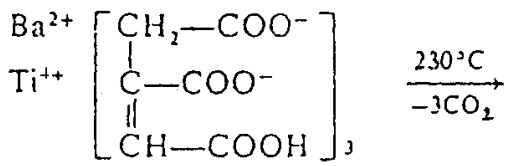

Aconitate

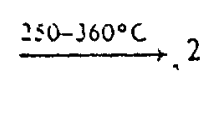<smiles>C=C1CO[O+]([O+])O1</smiles><smiles>C[13CH2]</smiles><smiles>C=C(C=O)CC(=O)OCC(=O)[O-]</smiles>

Itaconic anhydride

Scheme 2 Reaction of (Ba,Ti) citrate precursor during heating. ${ }^{13}$. 


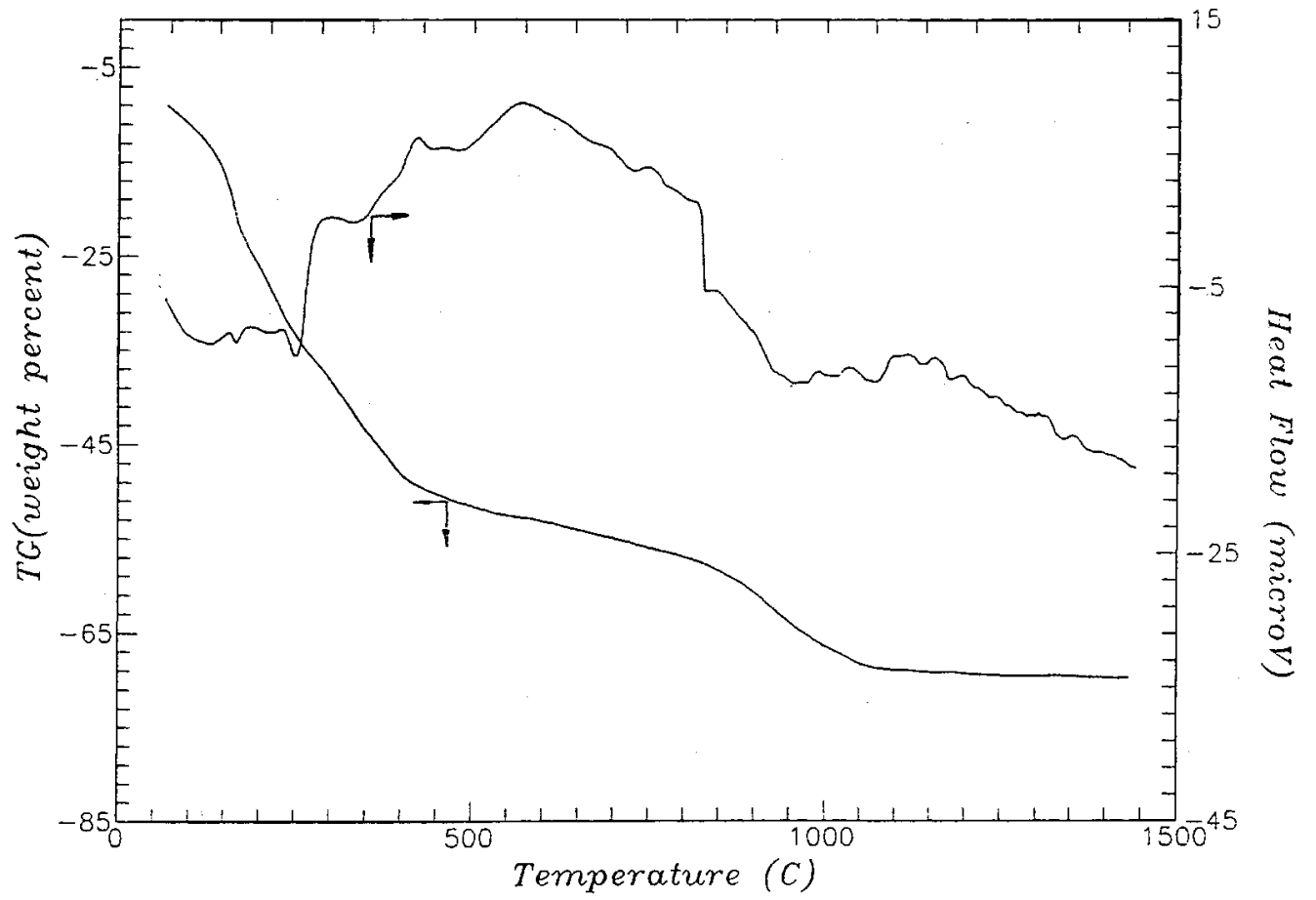

Figure 3 Thermogravimetric analysis (TGA) of the precursor at pH 5-6.

cation in the filtrate is minimized. The effect of ethanol is greater than that of acetone (Table 4).

\section{Precursor sintering studies}

\section{DSC/TGA analyses}

Figure 3 shows plots of heat flow and mass loss versus temperature for precursor formed at $\mathrm{pH}$ 5-6. The endotherm at $150-200^{\circ} \mathrm{C}$ represents loss of

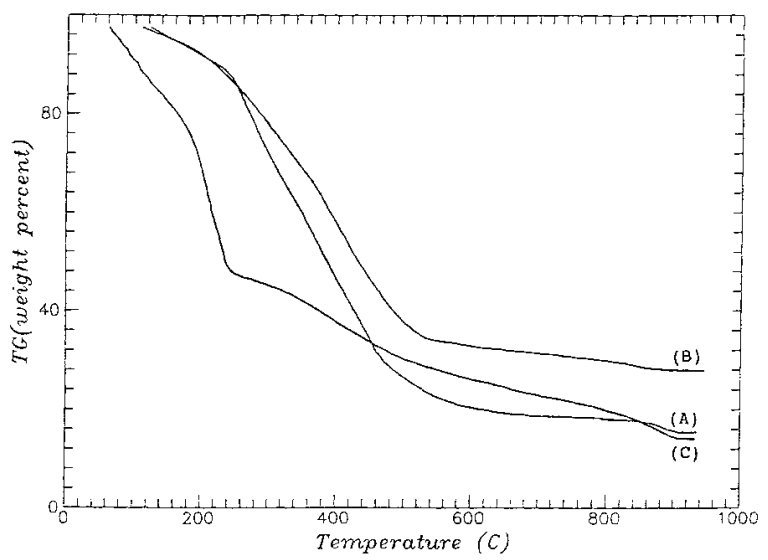

Figure 4 TGA of the precursors at: (A) pH 3-4; (B) pH 5-6; (C) $\mathrm{pH} 7-8$.

Copyright (C) 1999 John Wiley \& Sons, Ltd. water of hydration. The associated mass loss at $80{ }^{\circ} \mathrm{C}$ is about $8 \%$. DSC/TGA and IR analyses show that the formation of $\mathrm{CO}_{2}$ occurs at $200^{\circ} \mathrm{C}$. There is a large mass loss at $250-360^{\circ} \mathrm{C}$ due to itaconic anhydride from itaconate. The total mass loss is about $70 \%$, owing to the high percentage of organics in the precursor. The mass loss continues until $1000^{\circ} \mathrm{C}$. Therefore we chose $1100^{\circ} \mathrm{C}$ as the calcining temperature.

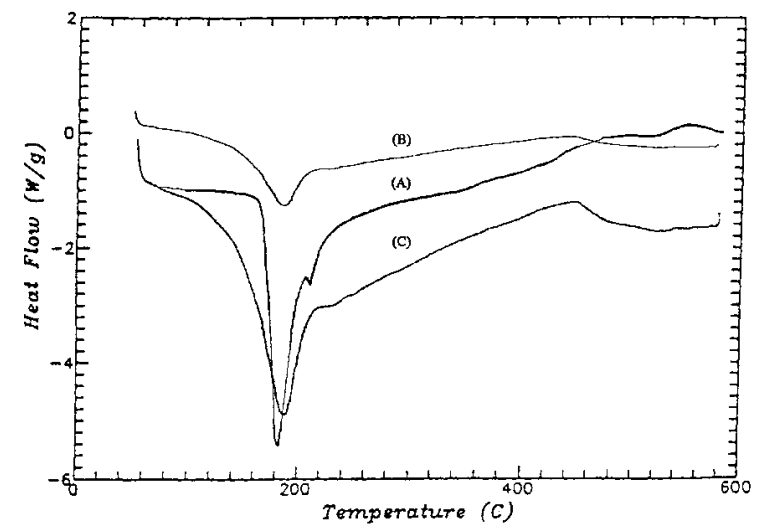

Figure 5 DSC of citrate precursors: (A) barium titanyl citrate; (B) strontium titanyl citrate; (C) barium strontium titanyl citrate.

Appl. Organometal. Chem. 13, 383-397 (1999) 


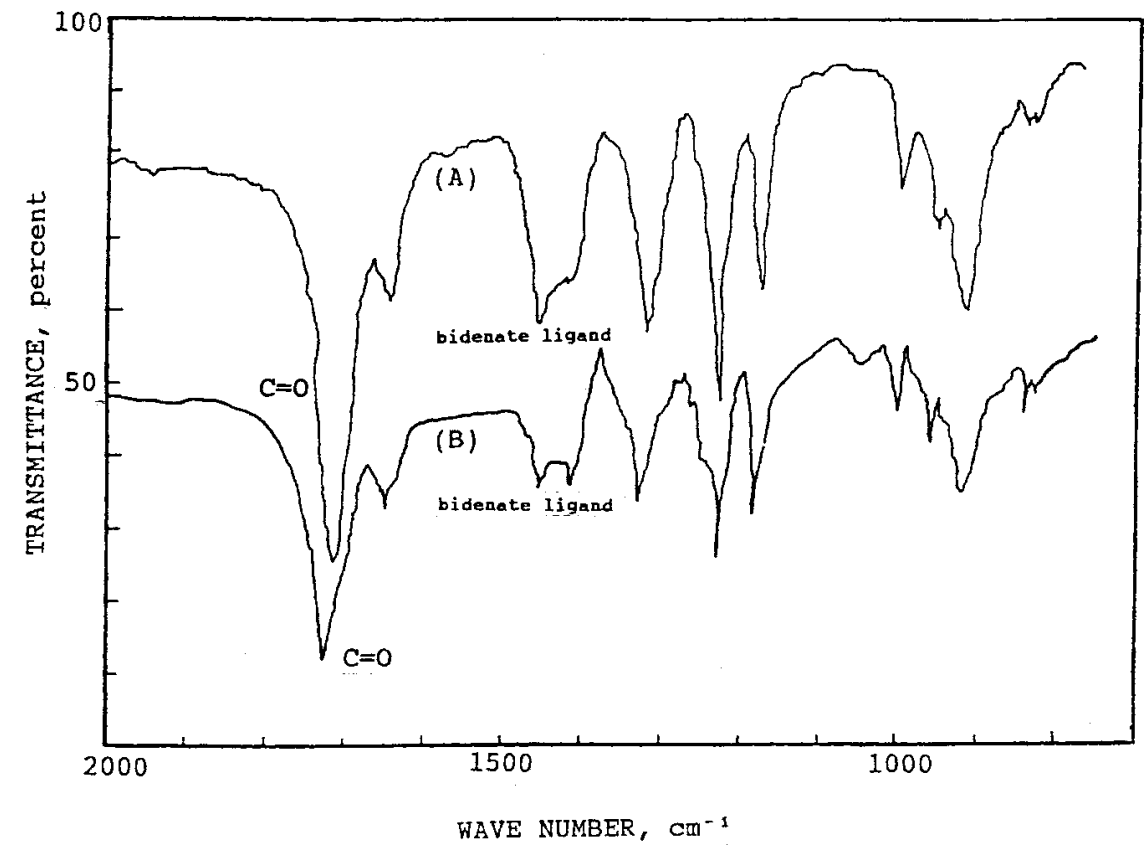

Figure 6 IR spectra of (A) itaconic acid ${ }^{13}$ and (B) the titanyl citrate precursor, both dried at $200^{\circ} \mathrm{C}$.

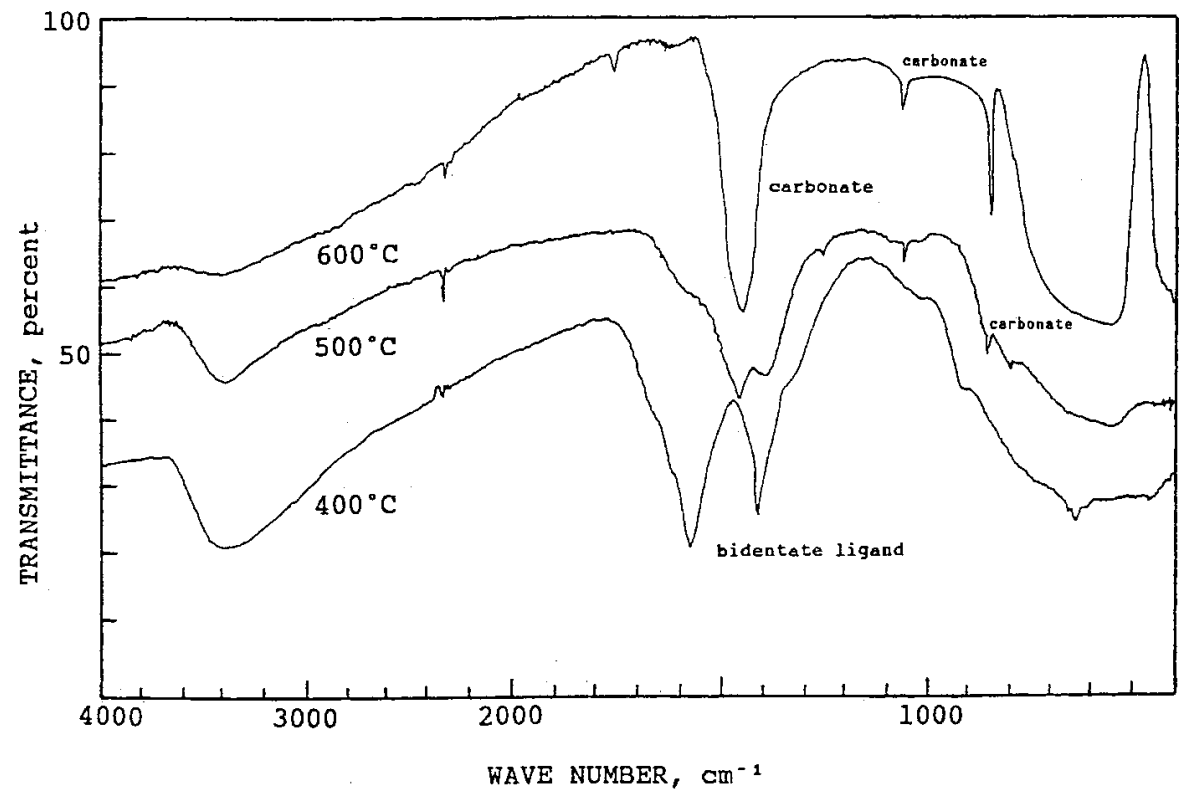

Figure 7 IR spectra of dried barium strontium titanyl citrate precursor at various temperatures.

The result of TGA of the precursor at various $\mathrm{pH}$ values is shown in Figure 4. There is a mass loss of $70 \%$ for precursor prepared at $\mathrm{pH} 5-6$ and $80-85 \%$ at $\mathrm{pH} 3-4$ and $7-8$. Therefore, more organics are present in the latter precursors than in those formulated at $\mathrm{pH} 5-6$. This means that more citrate is incorporated in the precursor at $\mathrm{pH} 3-4$ and $7-8$ than at $\mathrm{pH} 5-6$. 


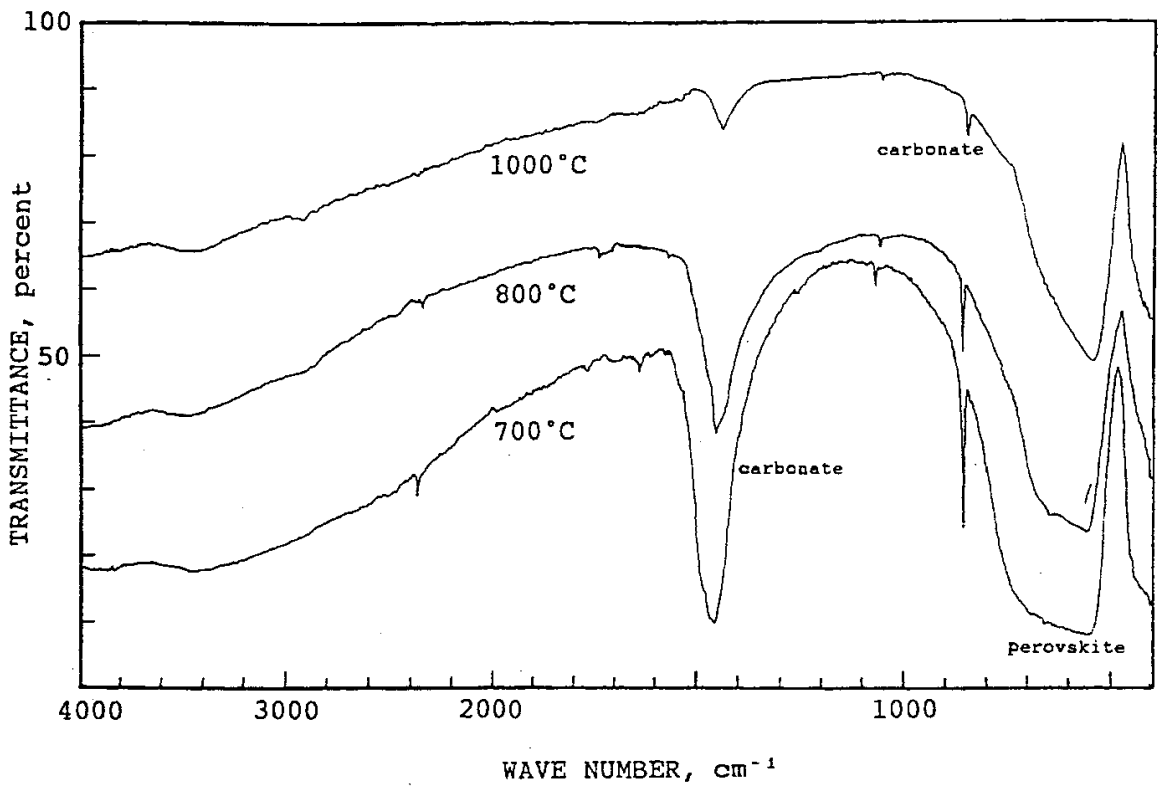

Figure 8 IR spectra of the titanyl precursor calcined at various temperatures for $8 \mathrm{~h}$.

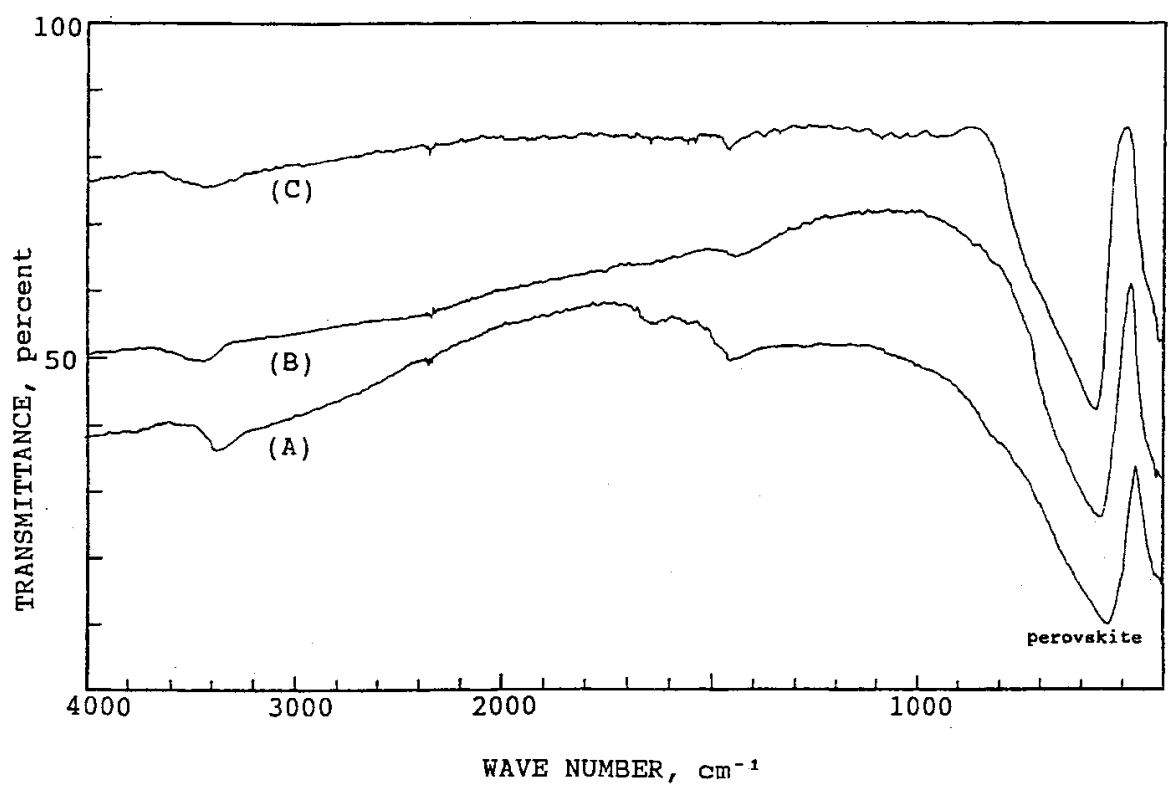

Figure 9 IR spectra of the different perovskite powders calcined at $1000{ }^{\circ} \mathrm{C}$ : (A) barium titanate; (B) barium strontium titanate; (C) strontium titanate.

In Figure 5, the (Ba,Ti), ( $\mathrm{Sr}, \mathrm{Ti})$ and $(\mathrm{Ba}, \mathrm{Sr}, \mathrm{Ti})$ citrates show similar DSC profiles. This suggests that the three precursors have similar chemical structures. According to a published DSC analysis of $(\mathrm{Ba}, \mathrm{Ti})$ citrate, ${ }^{13}$ the reactions shown in scheme 2 occur.

Copyright (C) 1999 John Wiley \& Sons, Ltd.

\section{IR analysis}

The IR spectra of itaconic acid and the titanyl citrates are shown in Figures 6-9. The IR spectrum of the titanyl citrate precursor dried at $200^{\circ} \mathrm{C}$ is similar to that of itaconic acid (Fig. 6). ${ }^{13}$ This suggests that the citrate precursor dried at $200{ }^{\circ} \mathrm{C}$ forms itaconic acid. 


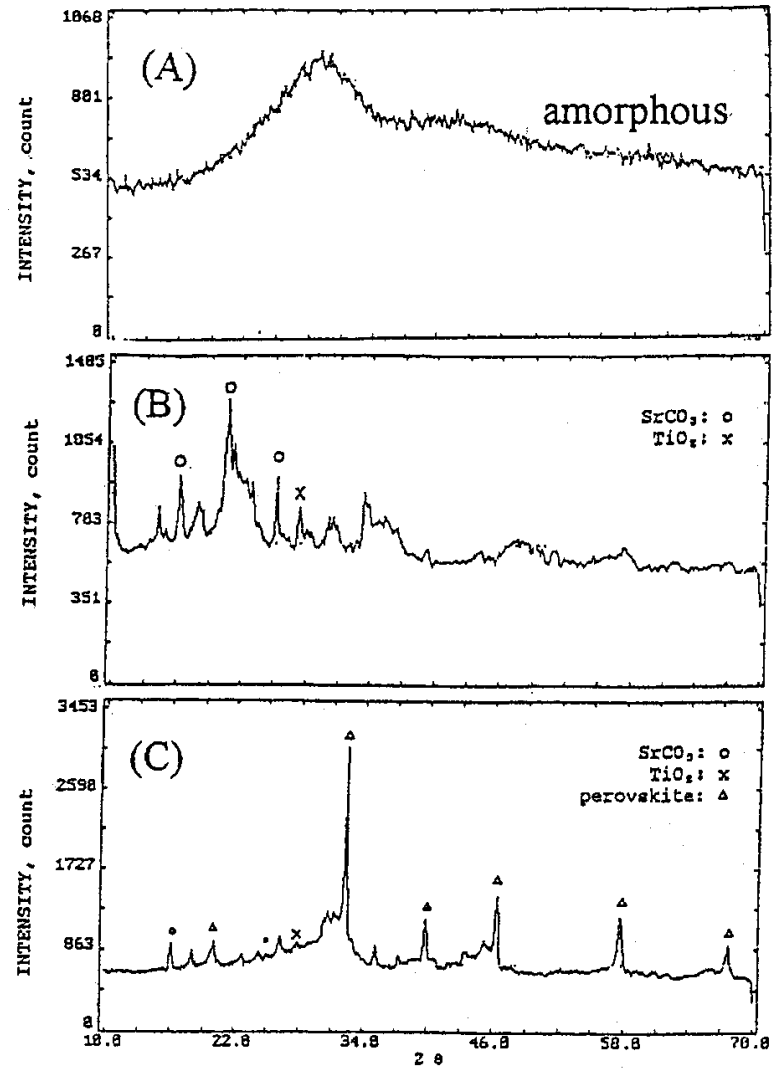

Figure 10 XRD patterns of the citrate precursor calcined for $8 \mathrm{~h}$ at (A) $400{ }^{\circ} \mathrm{C}$; (B) $500{ }^{\circ} \mathrm{C}$; (C) $600{ }^{\circ} \mathrm{C}$.

At $400{ }^{\circ} \mathrm{C}$, two absorption peaks appear at 1420 and $1560 \mathrm{~cm}^{-1}$ (Fig. 7). These bands are attributed to the bidentate ligand of $\mathrm{RCOO}^{-}{ }^{17}$ indicating the presence of $\mathrm{COO}^{-}$. At $500{ }^{\circ} \mathrm{C}$ absorption peaks at 860 , 1059 and $1460 \mathrm{~cm}^{-1}$ appear, indicating carbonate formation. ${ }^{18}$ The wide absorption band at $540 \mathrm{~cm}^{-1}$ at $600{ }^{\circ} \mathrm{C}$, suggests perovskite formation, ${ }^{19}$ even though $20 \mathrm{wt} \%$ carbonate is still present. Figure 8 shows the IR spectra of the titanyl citrate precursor heated to $700-1000{ }^{\circ} \mathrm{C}$. At $1000^{\circ} \mathrm{C}$ the $1460 \mathrm{~cm}^{-1}$ absorption peak decreases, indicating decomposition of carbonate. As shown in Figure 9, there is a perovskite band at $560 \mathrm{~cm}^{-1}$, which is supported by XRD results.

\section{XRD analysis}

The XRD patterns of the citrate precursor calcined at various temperatures for $8 \mathrm{~h}$ are shown in Figure 10. It is clear from Fig. 10 that the powder calcined below $500{ }^{\circ} \mathrm{C}$ is amorphous, and at $500{ }^{\circ} \mathrm{C}$ carbonates form as shown in the IR analysis.
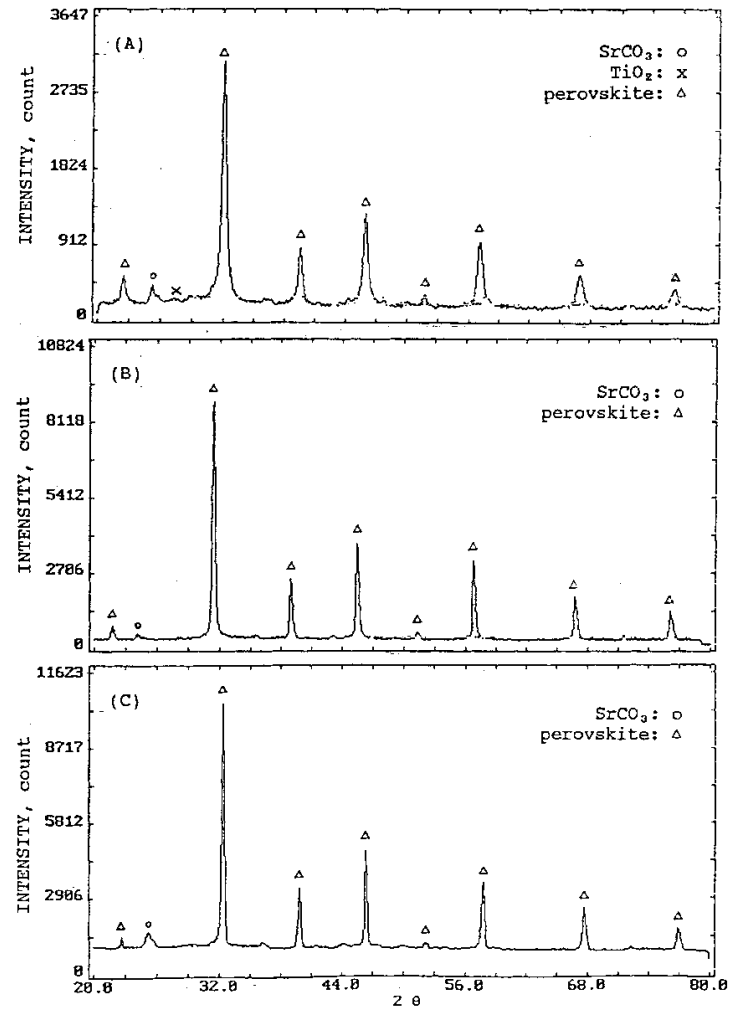

Figure 11 XRD patterns of $\mathrm{Ba}_{0.5} \mathrm{Sr}_{0.5} \mathrm{TiO}_{3}$ powder prepared by the citrate method at $1000^{\circ} \mathrm{C}$ for (A) $2 \mathrm{~h}$; (B) $4 \mathrm{~h}$; (C) $8 \mathrm{~h}$.

Comparison with JPCDS files indicates that at $500{ }^{\circ} \mathrm{C}$ the precursor decomposes to $\mathrm{BaCO}_{3}$ (11697), $\mathrm{SrCO}_{3}$ (5-418) and $\mathrm{TiO}_{2}$ (29-1360). At $600{ }^{\circ} \mathrm{C}$ the product is calcined to $(\mathrm{Ba}, \mathrm{Sr}) \mathrm{TiO}_{3}(39-$ 1395). The reaction is not complete at $600{ }^{\circ} \mathrm{C}$ as seen by XRD, as the spectra contain large amounts of $\mathrm{BaCO}_{3}, \mathrm{SrCO}_{3}$ and $\mathrm{TiO}_{2}$.

Figure 11 shows the patterns of $\mathrm{Ba}_{0.5} \mathrm{Sr}_{0.5} \mathrm{TiO}_{3}$ powder prepared by the citrate method and calcined at $1000^{\circ} \mathrm{C}$ for 2,4 and $8 \mathrm{~h}$, respectively. The carbonate and $\mathrm{TiO}_{2}$ contents (in Fig. 11) in the powder decrease and the crystallinity of perovskite increases with increasing time.

The XRD analysis of $\mathrm{Ba}_{0.5} \mathrm{Sr}_{0.5} \mathrm{TiO}_{3}$ powder prepared by solid-state reaction at $1000-1200{ }^{\circ} \mathrm{C}$ for $24 \mathrm{~h}$ is shown in Figure 12 . Heating at $1000{ }^{\circ} \mathrm{C}$ for $24 \mathrm{~h}$ produces powder with large amounts of impurities, including $\mathrm{BaCO}_{3}, \mathrm{SrCO}_{3}$ and $\mathrm{TiO}_{2}$. Only at $1200{ }^{\circ} \mathrm{C}$ do the amounts of impurities decrease significantly. In contrast, much lower reaction temperatures are required in the citrate method. The citrate precursor mix allows stoichio- 

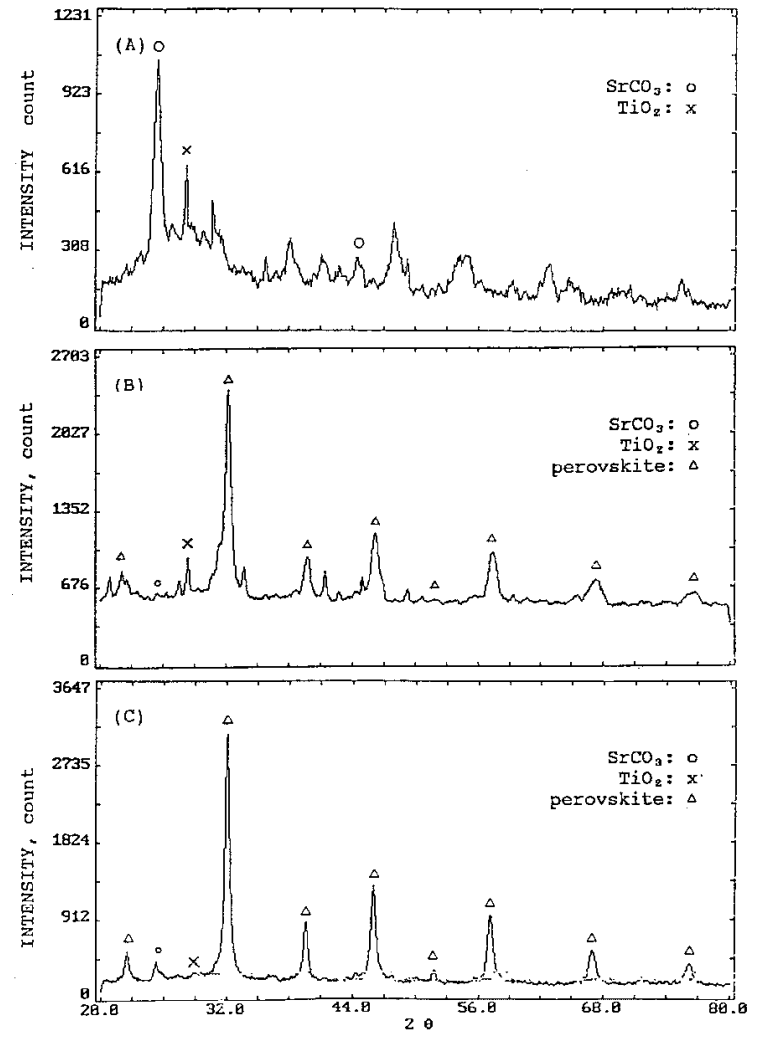

Figure 12 XRD patterns of $\mathrm{Ba}_{0.5} \mathrm{Sr}_{0.5} \mathrm{TiO}_{3}$ powder prepared by solid-state reaction for $24 \mathrm{~h}$ at (A) $1000^{\circ} \mathrm{C}$; (B) $1100^{\circ} \mathrm{C}$; (C) $1200^{\circ} \mathrm{C}$.

metric mixing and finer particle sizes of $\mathrm{BaCO}_{3}$, $\mathrm{SrCO}_{3}$ and $\mathrm{TiO}_{2}$, so that a shorter reaction path and larger contact areas occur, thereby decreasing the calcining temperature. ${ }^{20}$ The XRD patterns of sintered $\mathrm{Ba}_{0.5} \mathrm{Sr}_{0.5} \mathrm{TiO}_{3}$ produced by solid-state and citrate methods are shown in Figure 13, from which it is clear that the perovskite structure is very clean only at $1400{ }^{\circ} \mathrm{C}$ for the solid-state method, while the citrate method gives a clean material even at $1250{ }^{\circ} \mathrm{C}$. The grain sizes of the body sintered at $1400^{\circ} \mathrm{C}$ are larger.

\section{Properties of powder and sintering body}

\section{Mapping analysis}

Mapping analysis by SEM shows that the mixing of the cations in the ceramic body $\mathrm{Ba}_{0.5} \mathrm{Sr}_{0.5} \mathrm{TiO}_{3}$ using the citrate method is more uniform than that obtained by solid-state reaction.

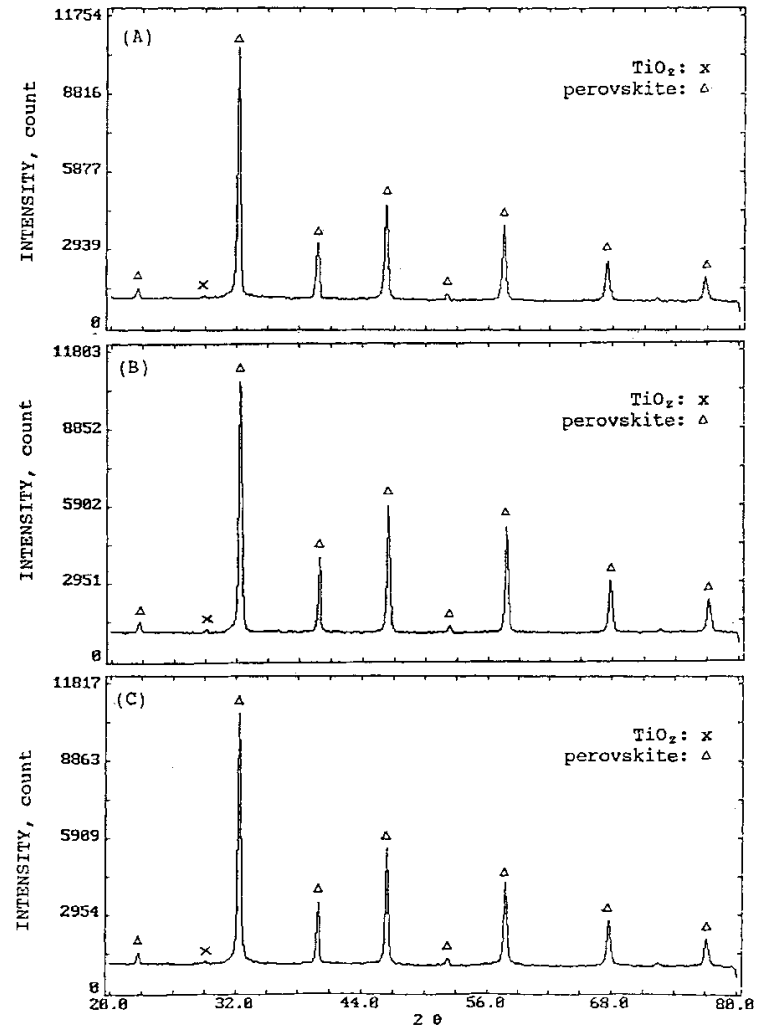

Figure 13 Comparison of XRD patterns of the sintering body of $\mathrm{Ba}_{0.5} \mathrm{Sr}_{0.5} \mathrm{TiO}_{3}$ prepared, during $24 \mathrm{~h}$, by (A) solid-state reaction at $1400^{\circ} \mathrm{C}$; (B) citrate method at $1250{ }^{\circ} \mathrm{C}$; (C) citrate method at $1400^{\circ} \mathrm{C}$.

\section{SEM analysis}

SEM (Fig. 14) of the titanyl citrate precursor, made by precipitating $\mathrm{Ti}\left(\mathrm{O}-\mathrm{iC}_{3} \mathrm{H}_{7}\right)_{4}$ or $\mathrm{TiCl}_{4}$ in acetone or absolute ethanol, shows that the particle size for titanyl citrate made from $\mathrm{TiCl}_{4}$ is smaller than for that made from $\mathrm{Ti}\left(\mathrm{O}-\mathrm{iC}_{3} \mathrm{H}_{7}\right)_{4}$, and the particle size made by precipitating $\mathrm{TiCl}_{4}$ in absolute ethanol is more uniform than that in acetone. Figure 15 shows the SEM of the perovskite powders prepared by the citrate method, dried in air or vacuum- or freezedried, and calcined at $1000{ }^{\circ} \mathrm{C}$ for $24 \mathrm{~h}$. The agglomeration of the freeze-dried powder is the lowest, while the oven-dried powder exhibits the greatest degree of agglomeration. The SEM of the perovskite powders of $\mathrm{BaTiO}_{3}, \mathrm{Ba}_{0.5} \mathrm{Sr}_{0.5} \mathrm{TiO}_{3}$ and $\mathrm{SrTiO}_{3}$ prepared by the citrate method and calcined at $1100^{\circ} \mathrm{C}$ for $8 \mathrm{~h}$ is shown in Figure 16. The particle sizes for these three powders are close $(0.4-$ $0.5 \mu \mathrm{m}$.

Appl. Organometal. Chem. 13, 383-397 (1999) 


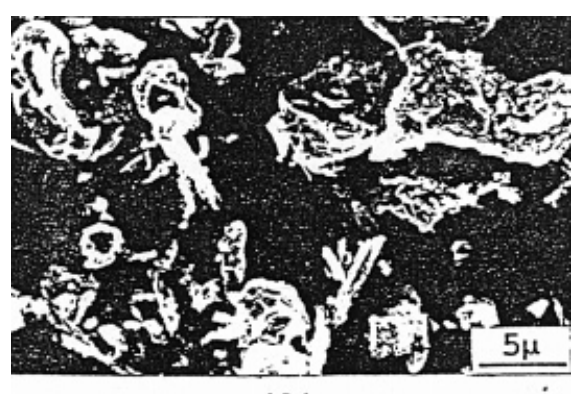

(A)

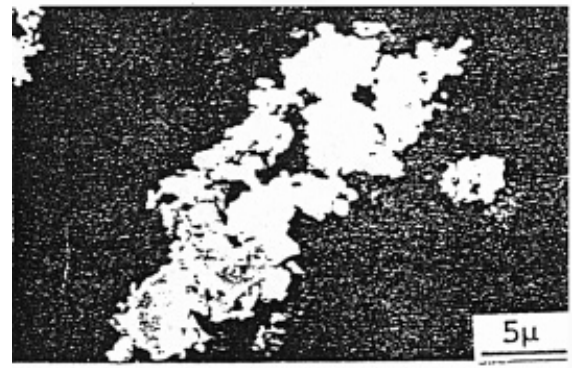

(B)

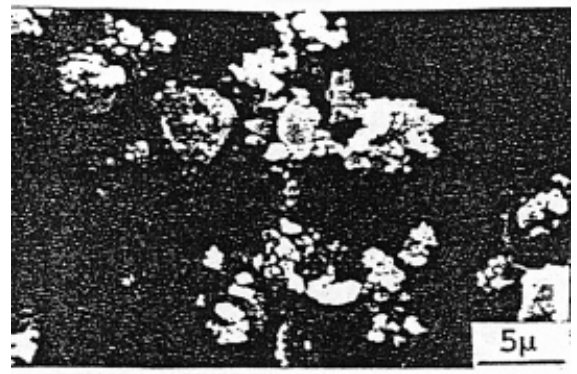

(C)

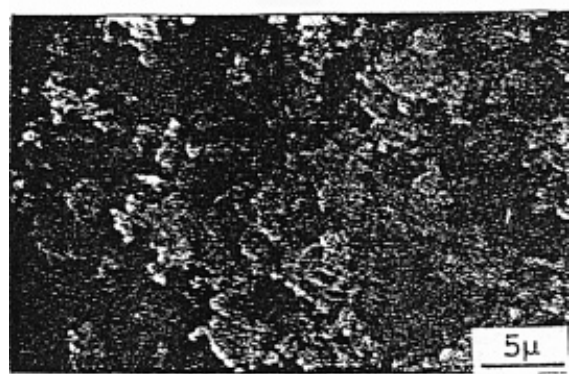

(D)

Figure 14 SEM of the titanyl citrate precursor, obtained (A) from $\mathrm{Ti}\left(\mathrm{O}-\mathrm{iC}_{3} \mathrm{H}_{7}\right)_{4} ;$ (B) from $\mathrm{TiCl}_{4} ;(\mathrm{C})$ by precipitating $\mathrm{TiCl}_{4}$ in acetone; (D) by precipitating $\mathrm{TiCl}_{4}$ in absolute ethanol.

Figure 17 shows the SEM of a sintered $\mathrm{Ba}_{0.5} \mathrm{Sr}_{0.5} \mathrm{TiO}_{3}$ body prepared by the citrate method at $1100,1200,1300$ and $1400^{\circ} \mathrm{C}$ for $4 \mathrm{~h}$. The pore

Copyright (C) 1999 John Wiley \& Sons, Ltd.

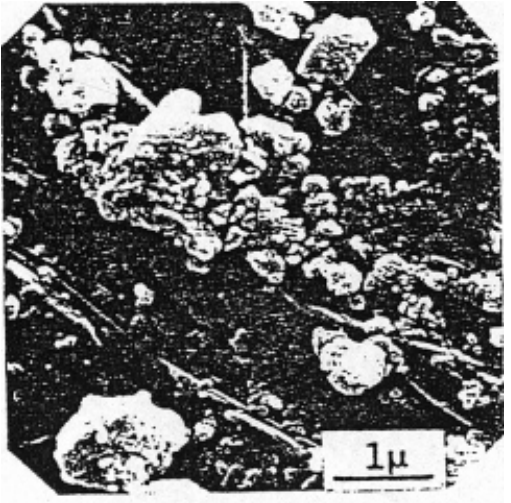

(A)

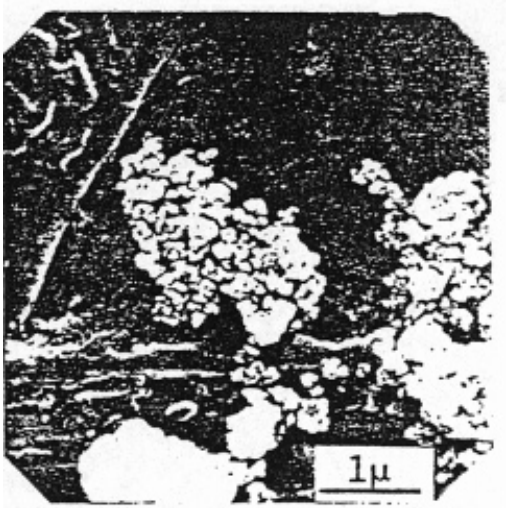

(B)

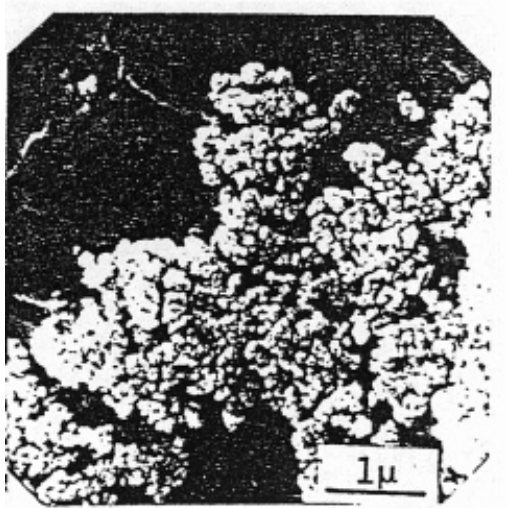

(C)

Figure 15 SEM of the perovskite powders prepared by the citrate method and calcined at $1000^{\circ} \mathrm{C}$ for $24 \mathrm{~h}$, after (A) airdrying; (B) vacuum-drying; (C) freeze-drying.

volume is $16 \%$ and $10 \%$ for the sintering body at 1100 and $1200^{\circ}$, respectively, so the body is not dense. At $1300^{\circ} \mathrm{C}$ only 6 vol. $\%$ porosity remains

Appl. Organometal. Chem. 13, 383-397 (1999) 


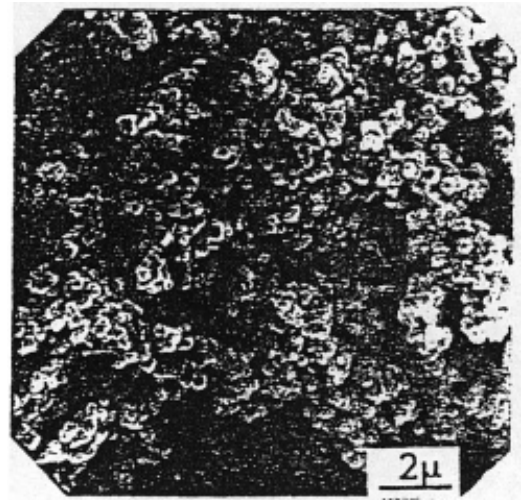

(A)

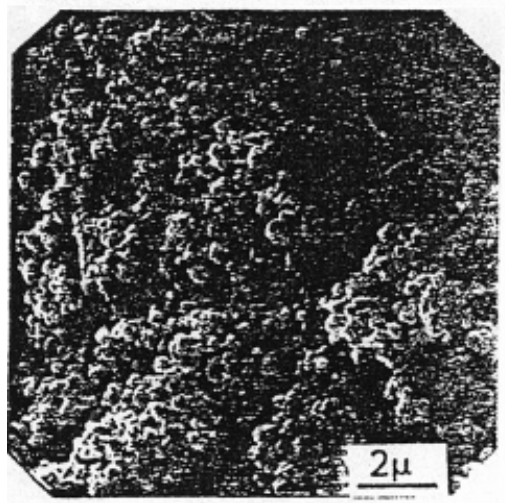

(B)

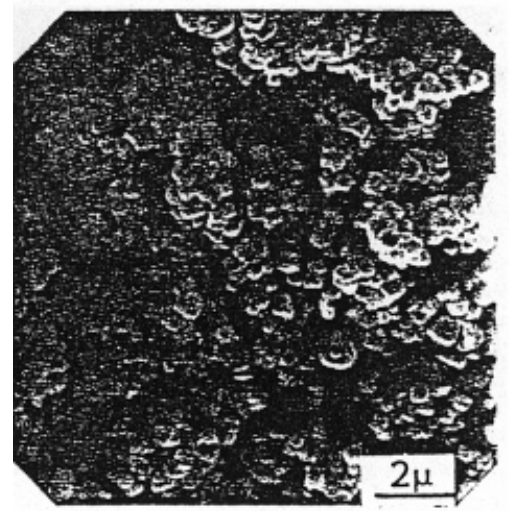

(C)

Figure 16 SEM of the perovskite powders prepared by the citrate method and calcined at $1000{ }^{\circ} \mathrm{C}$ for $8 \mathrm{~h}$ : (A) $\mathrm{BaTiO}_{3}$; (B) $\mathrm{Ba}_{0.5} \mathrm{Sr}_{0.5} \mathrm{TiO}_{3} ;(\mathrm{C}) \mathrm{SrTiO}_{3}$.

and at $1400{ }^{\circ} \mathrm{C}$ only $1 \mathrm{vol} \%$ porosity is found, indicating considerable improvement in density.

Micrographs of the sintered $\mathrm{Ba}_{0.5} \mathrm{Sr}_{0.5} \mathrm{TiO}_{3}$ body

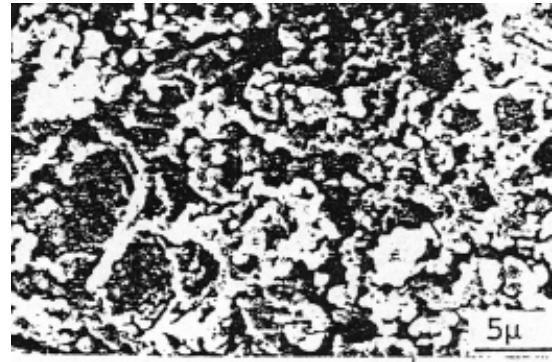

(A)

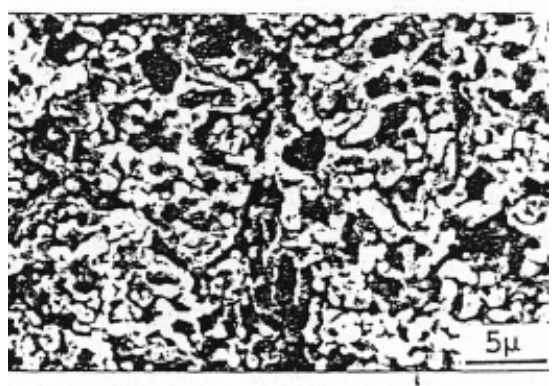

(B)

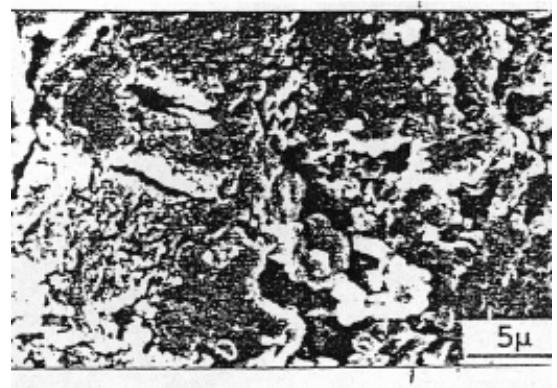

(C)

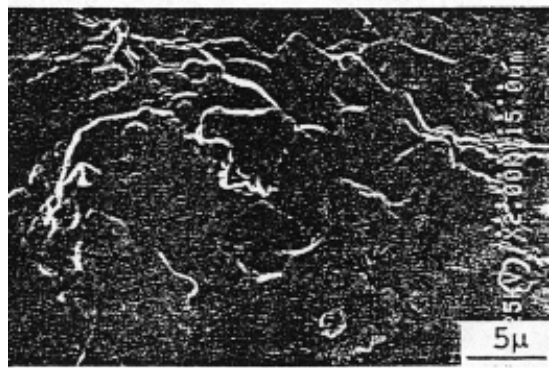

(D)

Figure 17 SEM of sintered $\mathrm{Ba}_{0.5} \mathrm{Sr}_{0.5} \mathrm{TiO}_{3}$ body prepared by the citrate method during $4 \mathrm{~h}$ at $(\mathrm{A}) 1100{ }^{\circ} \mathrm{C}$; (B) $1200{ }^{\circ} \mathrm{C}$; (C) $1300{ }^{\circ} \mathrm{C}$; (D) $1400^{\circ} \mathrm{C}$.

prepared using the solid-state-derived powders method at 1300,1400 and $1450^{\circ} \mathrm{C}$ for $4 \mathrm{~h}$ are shown in Figure 18. The porosity is 13 and $7 \%$ at 


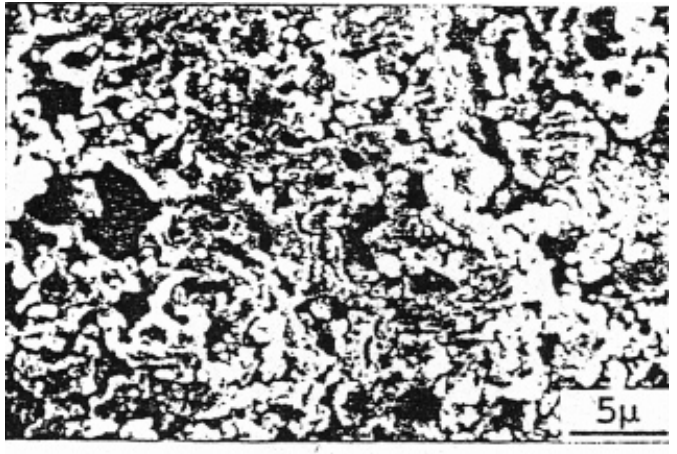

(A)

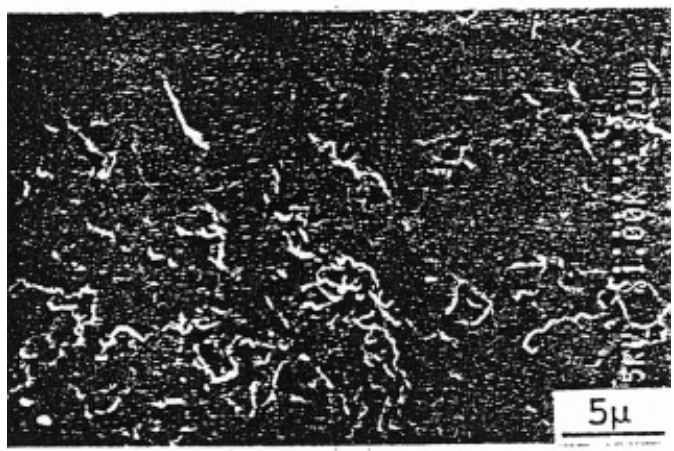

(B)

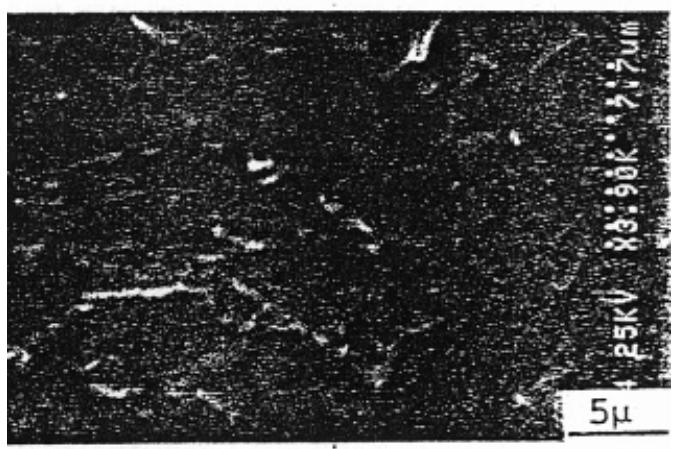

(C)

Figure $18 \mathrm{SEM}$ of sintered $\mathrm{Ba}_{0.5} \mathrm{Sr}_{0.5} \mathrm{TiO}_{3}$ body prepared by solid-state reaction during $4 \mathrm{~h}$ at (A) $1300^{\circ} \mathrm{C}$; (B) $1400^{\circ} \mathrm{C}$; (C) $1450{ }^{\circ} \mathrm{C}$.
1300 and $1400{ }^{\circ} \mathrm{C}$, respectively. However, at $1450{ }^{\circ} \mathrm{C}$ only $1 \mathrm{vol} . \%$ porosity remains and the compact is close to theoretical density.

\section{Measurement of specific surface area}

The specific surface areas of the $\mathrm{Ba}_{0.5} \mathrm{Sr}_{0.5} \mathrm{TiO}_{3}$ citrate precipitate dried in air, vacuum or by freezedrying and calcined at $1000{ }^{\circ} \mathrm{C}$ for $8 \mathrm{~h}$ were measured by the BET method. The results are listed in Table 5. The agglomeration of the freezedried precursor and of the freeze-dried and calcined powder prepared from citrate are the least; it was hence their specific surfaces were the greatest (Table 5). The specific surface area obtained by airdrying is the lowest, due to a greater degree of agglomeration. ${ }^{21}$

\section{Chemical compositions of the body}

The chemical compositions of the $\mathrm{Ba}_{0.5} \mathrm{Sr}_{0.5} \mathrm{TiO}_{3}$ citrate powder were analysed chemically by AA; Table 6 shows that the cation ratios are nearest those of the original stoichiometry in the $\mathrm{pH} 5-6$ range. When the $\mathrm{pH}$ of the preparatory solution is lower, the deviation of $\mathrm{Sr}^{2+}$ is greatest (Table 6). This is due to the poor precipitation of the strontium citrate precursor in acid solution. ${ }^{22}$ At $\mathrm{pH} 7-8$, the deviation of $\mathrm{Ba}^{2+}$ is the greatest due to the solubility of the barium citrate precursor in neutral solution.

\section{Determination of bulk density}

The changes in bulk density of $\mathrm{Ba}_{0.5} \mathrm{Sr}_{0.5} \mathrm{TiO}_{3}$, dried in air or vacuum- or freeze-dried and then calcined at $1000{ }^{\circ} \mathrm{C}$ for $8 \mathrm{~h}$, and sintered at various temperatures, are shown in Figure 19. The bulk density increased with increasing sintering temperature, as expected, with the compact obtained by freeze-drying reaching the highest densities at temperatures around $1300^{\circ} \mathrm{C}$. The compact made using air-dried powders requires $1400{ }^{\circ} \mathrm{C}$ sintering to reach full density, owing to high initial agglomeration and the large size of the pores after sintering.

Figure 20 shows the changes in the bulk densities of $\mathrm{BaTiO}_{3}, \mathrm{Ba}_{0.5} \mathrm{Sr}_{0.5} \mathrm{TiO}_{3}$ and $\mathrm{SrTiO}_{3}$ obtained by

Table 5. Specific surface areas for $\mathrm{Ba}_{0.5} \mathrm{Sr}_{0.5} \mathrm{TiO}_{3}$

\begin{tabular}{|c|c|c|c|c|c|c|}
\hline \multirow[b]{2}{*}{ Drying method } & \multicolumn{3}{|c|}{ Citrate gel } & \multicolumn{3}{|c|}{ Calcined powder } \\
\hline & $\begin{array}{c}\text { Air- } \\
\text { drying }\end{array}$ & $\begin{array}{l}\text { Vacuum- } \\
\text { drying }\end{array}$ & $\begin{array}{c}\text { Freeze- } \\
\text { drying }\end{array}$ & $\begin{array}{c}\text { Air- } \\
\text { drying }\end{array}$ & $\begin{array}{l}\text { Vacuum- } \\
\text { drying }\end{array}$ & $\begin{array}{l}\text { Freeze- } \\
\text { drying }\end{array}$ \\
\hline Surface area $\left(\mathrm{m}^{2} \mathrm{~g}^{-1}\right.$ & 20.8 & 25.2 & 29.8 & 8.3 & 10.2 & 12.5 \\
\hline
\end{tabular}


Table 6. Chemical compositions of the perovskite powders from citrate precursor

\begin{tabular}{|c|c|c|c|c|}
\hline \multirow[b]{2}{*}{$\mathrm{pH}$ range of preparation } & \multicolumn{2}{|c|}{ Org. chemical composition } & \multicolumn{2}{|c|}{ Powder chemical composition } \\
\hline & $\mathrm{Ba} / \mathrm{Ti}$ ratio & $\mathrm{Sr} / \mathrm{Ti}$ & $\mathrm{Ba} / \mathrm{Ti}$ & $\mathrm{Sr} / \mathrm{Ti}$ \\
\hline $2-3$ & $1: 2$ & $1: 2$ & 0.44 & 0.42 \\
\hline $2-3$ & $1: 1$ & 0 & 0.99 & - \\
\hline $3-4$ & $1: 2$ & $1: 2$ & 0.46 & 0.46 \\
\hline $4-5$ & $1: 2$ & $1: 2$ & 0.51 & 0.52 \\
\hline $5-6$ & $1: 2$ & $1: 2$ & 0.48 & 0.49 \\
\hline $5-6$ & 0 & $1: 1$ & - & 0.98 \\
\hline $7-8$ & $1: 2$ & $1: 2$ & 0.23 & 0.34 \\
\hline
\end{tabular}

freeze-drying and sintered at various temperatures. The sintering temperature of $\mathrm{BaTiO}_{3}$ is lower, about $1300^{\circ} \mathrm{C}$, and that of $\mathrm{SrTiO}_{3}$ is higher, about $1425^{\circ} \mathrm{C}$.

\section{Perovskite powder crystallite sizes}

The $\mathrm{BaTiO}_{3}, \mathrm{Ba}_{0.5} \mathrm{Sr}_{0.5} \mathrm{TiO}_{3}$ and $\mathrm{SrTiO}_{3}$ powder grain sizes after calcining at $1100{ }^{\circ} \mathrm{C}$ for $8 \mathrm{~h}$ were measured using the XRD $31-33^{\circ}\left(2 \theta=32.2^{\circ}\right)$ peak, which is the (110) face of perovskite by Scherrer's formula (Eqn [5]).

$$
\varepsilon=\lambda /(\beta \cos \theta)
$$

The calculated grain sizes are listed in Table 7.

The crystallite sizes obtained using the citrate

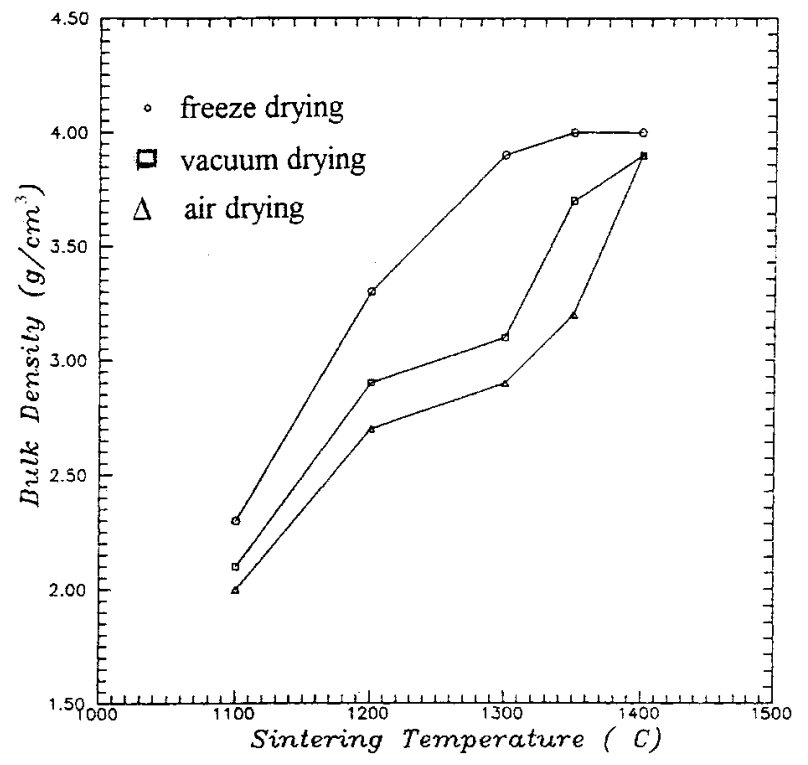

Figure 19 Changes in bulk density with increasing sintering temperature of $\mathrm{Ba}_{0.5} \mathrm{Sr}_{0.5} \mathrm{TiO}_{3}$ obtained by various drying modes.

Copyright (C) 1999 John Wiley \& Sons, Ltd. method are larger than those from the solid-state reaction, because the initial uniform mixing leads to shortening of the diffusion paths, compared with solid-state mixing. Hence grains form faster and grow longer for any given sintering temperature and time.

\section{CONCLUSIONS}

The DSC/TGA and IR data provide a clear picture of the thermogravimetric behaviour and chemical changes occuring in the citrate precursor during calcination The precursor is converted at $500{ }^{\circ} \mathrm{C}$ to

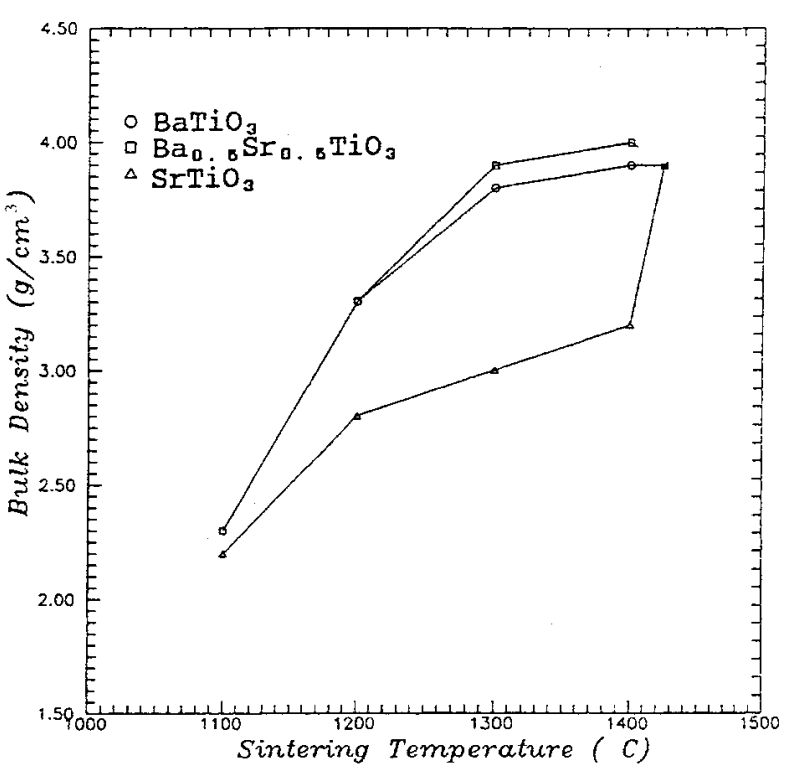

Figure 20 Changes in bulk densities of $\mathrm{BaTiO}_{3}, \mathrm{Ba}_{0.5} \mathrm{Sr}_{0.5}$ $\mathrm{TiO}_{3}$ and $\mathrm{SrTiO}_{3}$ with increasing sintering temperature.

Appl. Organometal. Chem. 13, 383-397 (1999) 
Table 7. Crystallite sizes for perovskite powders calculated by Debye-Scherrer method

\begin{tabular}{|c|c|c|c|c|c|c|}
\hline & \multicolumn{6}{|c|}{ Preparation method } \\
\hline & \multicolumn{3}{|c|}{ Solid-state reaction } & \multicolumn{3}{|c|}{ Citrate method } \\
\hline & $\mathrm{BaTiO}_{3}$ & $\mathrm{SrTiO}_{3}$ & $\begin{array}{c}(\mathrm{Ba}, \mathrm{Sr}) \\
\mathrm{TiO}_{3}\end{array}$ & $\mathrm{BaTiO}_{3}$ & $\mathrm{SrTiO}_{3}$ & $\begin{array}{c}(\mathrm{Ba}, \mathrm{Sr}) \\
\mathrm{TiO}_{3}\end{array}$ \\
\hline Crystallite size $(\AA)$ & 120 & 140 & 140 & 210 & 230 & 225 \\
\hline
\end{tabular}

carbonate, which begins to react with $\mathrm{TiO}_{2}$ to form $(\mathrm{Ba}, \mathrm{Sr}) \mathrm{TiO}_{3}$ powders at $600{ }^{\circ} \mathrm{C}$. This powder can finally be transformed to product by calcining at $1100^{\circ} \mathrm{C}$.

The ratios of the cations in the powder are the nearest to the original stoichiometry in the $\mathrm{pH} 5-6$ range, where the concentration of cation in the filtrate is only $0.1 \mathrm{~mol} \%$. The effect of absolute ethanol on precipitation is much greater than that of acetone, and one can obtain a completely dry precipitate with ethanol.

The specific surface area of the calcined $\mathrm{Ba}_{0.5} \mathrm{Sr}_{0.5} \mathrm{TiO}_{3}$ powder is $12.5 \mathrm{~m}^{2} \mathrm{~g}^{-1}$ by the BET method, and the crystallite size of the $\mathrm{Ba}_{0.5} \mathrm{Sr}_{0.5}$ $\mathrm{TiO}_{3}$ powder using the citrate method is about $225 \AA(2.2 \mu \mathrm{m})$ by XRD.

Among the drying modes, freeze-drying is best as it minimizes agglomeration. When the precipitated titanyl citrate powders that had been freezedried and calcined at $1100{ }^{\circ} \mathrm{C}$ were compacted, and sintered at $1300{ }^{\circ} \mathrm{C}$, densities as high as $95 \%$ of theoretical were achieved.

Acknowledgements The authors thank the National Science Council, NSC 85-2214-E006-003, for the financial support of this work.

\section{REFERENCES}

1. K. Kiss, J. Magder, M. S. Vukasovich, and R. J. Lockhart, J. Am. Ceram. Soc. 49(6), 291 (1966).

2. H. Yamamura, Ceram. Int. 11(1), 17 (1985).

3. P. Sainamthip, and R. W. Amarkoon, J. Am. Ceram. Soc. 71(2), C-92 (1988).

4. W. S. Clabaugh, E. M. Swiggerd, and R. Gilchrist, J. Res. Natl. Bur. Std., 56(5), 289 (1956).

5. K. Kudaka, K. Iizumi, and K. Sasaki, Am. Ceram. Bull. 61, 1236 (1982).
6. B. A. Tuttle, Ceram. Powder 62 (1987).

7. E. Andrich, Electron. Appl. 26(3), 123 (1966).

8. D. E. Rase, and R. Roy, J. Am. Ceram. Soc. 38, 102 (1955).

9. E. Andrich, Electron. Appl. 25, 123 (1965).

10. D. Hennings, Br. Ceram. Proc. 41, 1 (1989).

11. E. Wu, K. C. Chen, and J. D. Mackenzie, Ferroelectric ceramics-the sol-gel versus conventional processing. In: Better Ceramics Through Chemistry, Brinker, C. J., Clark, D. E. and Ulrich, D. R., (eds), Materials Research Society Symposia Proc., Vol. 32, Elsevier Science North-Holland, 1984, pp. 169-174.

12. K. D. Budd, and D. A. Payne, Preparation of strontium titanate ceramics and internal boundary layer capacitors by the Pechini method. In: Better Ceramics Through Chemistry, Brinker, C. J., Clark, D. E. and Ulrich, D. R., (eds), Materials Research Society Symposia Proc., Vol. 32, Elsevier Science, North-Holland, 1984, pp. 239-244.

13. D. Hennings, and W. Mayr, J. Solid State Chem. 26, 329 (1978).

14. P. P. Phule, and S. H. Risbud, J. Mater. Sci. 25, 1169 (1990).

15. L. A. Xue, F. L. Riley, and R. J. Brook, Br. Ceram. Trans. J. 85, 47 (1987).

16. C. E. Li, H. Y. Ni, and Z. W. Yin, Ceram. Powder 539 (1987).

17. S. Doeuff, M. Henry, C. Sanchez, and J. Livage, J. NonCryst. Solids 89, 206 (1987).

18. R. E. Riman, D. M. Haaland, C. J. M. Northrup, Jr, N. K. Bowen, and A. Bleier, An infrared study of metal isopropoxide precursors for $\mathrm{SrTiO}_{3}$. In: Better Ceramics Through Chemistry, Brinker, C. J., Clark, D. E. and Ulrich, D. R., (eds), Materials Research Society Symposia Proc., Vol. 32, Elsevier Science North-Holland, 1984, pp. 233238.

19. B. Samuneva, S. Jambazov, D. Lepkova, and Y. Dimitriev, Ceram. Int. 16, 355 (1990).

20. P. P. Phule, and S. H. Risbud, Mater. Sci. Eng. B3, 241 (1989).

21. K. H. Jo, and K. H. Yoon, Mater. Res. Bull. 24, 1 (1989).

22. M. V. Raymond, and V. R. W. Amarakoon, J. Am. Ceram. Soc. 73(5), 1308 (1990). 